\title{
Mirosław KoseK
}

Uniwersytet Kardynała Stefana Wyszyńskiego

\section{UZALEŻNIENIE OD INTERNETU JAKO JEDNA Z PRZYCZYN ROZWODU}

\section{WPROWADZENIE}

Problematyka przyczyn rozkładu pożycia małżeńskiego i w konsekwencji rozwodu była wielokrotnie przedmiotem zainteresowania badaczy - prawników, socjologów, pedagogów, także psychologów ${ }^{1}$. Wynikało to bez watpienia ze znaczenia tej problematyki dla trwałości małżeństwa i rodziny w perspektywie ich skutecznej ochrony. Trwałość związku małżeńskiego i powstałej poprzez jego zawarcie rodziny jest wartością niekwestionowana, stanowiącą przedmiot szczególnej ochrony. Poznanie czynników (tak wewnętrznych, jak i zewnętrznych), które mają negatywny wpływ na tę trwałość i ich analiza jest jednym z warunków skutecznej ochrony. W tym aspekcie problematyka przyczyn rozwodu pozostaje ciągle aktualna.

W literaturze spotkać można różne propozycje klasyfikacji przyczyn rozkładu pożycia. J. Suwart ujmuje je w cztery kategorie: przyczyny psychologiczne (np. brak wspólnych zainteresowań, nerwowość, alkoholizm, różne cechy charakteru), obiektywne (np. warunki material-

1 Por. J. GóRecki, Rozwód. Studium socjologiczno-prawne, Warszawa 1965; W. Stojanowska, Problematyka rozwodów w świetle badań, Warszawa 1978; A. OlejniczaK, Materialnoprawne przesłanki udzielenia rozwodu, Poznań 1980; E. Rosset, Rozwody, Warszawa 1986. 
ne, trudności w pracy zawodowej), macierzyńsko-pedagogiczne (np. nieporozumienia na tle wychowania dziecka) oraz przyczyny dotyczące naruszenia wierności małżeńskiej (np. zdrada, nieuzasadniona zazdrość $)^{2}$. Badania dotyczące omawianej problematyki wskazują, że najczęstszą przyczyną rozwodu, obok niewierności, jest alkoholizm jednego z małżonków. Pojawia się on najczęściej jako samodzielna przyczyna, a niekiedy także w formule ,alkoholizm i inne nałogi”3. Nadużywanie alkoholu i jego negatywne społeczne skutki nie wymagają rozwinięcia. Problem ten, którym dotknięta jest, niestety, zdecydowana większość polskich rodzin, został wszechstronnie opracowany z punktu widzenia różnych dyscyplin naukowych. Nową natomiast rzeczywistościa, przybierającą coraz większe rozmiary, są inne formy uzależnień, których skutki są równie przerażające, jak w przypadku alkoholizmu, chociaż nie tak powszechnie znane.

Celem artykułu jest ukazanie uzależnienia od Internetu jako jednej z przyczyn rozwodu. Najpierw omawiane będzie samo zjawisko uzależnienia i jego skutki, następnie zaprezentowane zostaną badania dotyczące wpływu uzależnienia od Internetu na rozkład pożycia małżeńskiego.

\section{FENOMEN INTERNETU - KRÓTKA CHARAKTERYSTYKA ZJAWISKA}

Ocena określonego zjawiska wymaga wcześniejszego jego poznania. Konieczne wydaje się zatem poprzedzenie zasadniczych rozważań, swoistym wprowadzeniem, które pozwoli, przynajmniej w pewnym zakresie, zrozumieć istotę i złożoność analizowanego fenomenu.

Początki Internetu sięgają przełomu lat 60-tych i 70-tych ubiegłego stulecia i mają korzenie stricte militarne ${ }^{4}$. W okresie zimnej wojny Departament Obrony USA powierzył jednej ze swych agencji zadanie

2 Por. J. SuwART, Konflikty matżeńskie w świetle badań socjologicznych, «Problemy Rodziny» $1967 \mathrm{nr}$ 2, s. 11.

3 Por. W. StojanowsKa, op. cit., s. 71.

${ }^{4}$ Szerzej na ten temat por. M. ZIELIŃSKI, www.winter.pl/Internet/powtanie.html; por. także K. KaliszewsKa, Nadmiernie używanie Internetu. Charakterystyka psychologiczna, Poznań 2007, s. 13-14. 
stworzenia sieci połączeń pomiędzy najważniejszymi stanowiskami taktycznymi. Powstałą w takich okolicznościach wojskową sieć połączeń komputerowych nazwano ARPANET (od nazwy agencji powołanej do jej opracowania: Advanced Research Project Agency Network). Sukces projektu i ogromne możliwości, które wprowadzał, wpłynęły na dalszy jego rozwój. W latach 80-tych rząd USA powołał Narodową Fundację ds. Nauki (National Science Foundation), zlecając jej utworzenie podobnej sieci do celów badawczych. Powstała w ten sposób NSFNET, przekształcona następnie w dzisiejszy Internet. Krokiem milowym w rozwoju Internetu okazało się utworzenie w 1991 roku przez Europejską Radę ds. Badań Nuklearnych nowej struktury sieci, ułatwiającej dostęp do informacji w niej zawartych. Tym nowym nośnikiem stały się strony WWW (World Wide Web).

Internet $\mathrm{w}$ jego dzisiejszej postaci tworzą trzy powiązane ze sobą elementy: połączone sieci oparte o protokoły TCP/IP, społeczność, która używa i rozwija tę sieć oraz zbiór zasobów znajdujących się w tej siecis ${ }^{5}$. Ujęcie to pozwala rozróżnić trzy zasadnicze aspekty fenomenu Internetu: aspekt techniczny, informacyjny i społeczny. Każdy z wymienionych aspektów stanowi odrębny, obszerny temat. Warto w tym miejscu poświęcić więcej uwagi informacyjnemu wymiarowi przedmiotowego zagadnienia, by łatwiej uchwycić aspekt w tych rozważaniach najważniejszy - wymiar społeczny.

Na Internet składa się wiele ,środowisk” lub obszarów aktywności wirtualnej ${ }^{6}$. Pierwsze z nich tworzą wspomniane już strony WWW ogromny zbiór informacji, którym użytkownicy posługują się w celu wyszukiwania potrzebnych danych. Powstanie tego nośnika informacji zrewolucjonizowało prawie każdą dziedzinę życia. Zarówno osoba fizyczna, jak i instytucja ma możliwość stworzenia własnej strony internetowej, dla prezentacji siebie, swej firmy, promocji innych form aktywności. I tak np. każdy z liczących się tytułów prasowych ukazuje się również w wersji elektronicznej, każda szanująca się firma posiada

${ }^{5}$ Por. A. JAKUBIK, Zespót uzależnienia od Internetu, «Studia Psychologica [UKSW]» 3 (2002), s. 134.

${ }^{6}$ Por. P. Wallace, Psychologia Internetu, Poznań 2003, s. 11 i n. 
własną stronę internetową, która w dużym stopniu warunkuje dalszy jej rozwój. Zdecydowana większość usług, począwszy od prostych zakupów, poprzez wybór ofert turystycznych, aż po usługi bankowe, jest dziś dokonywana na pomocą Internetu. Wprost trudno wyobrazić sobie naszą codzienność bez stron WWW.

Drugim środowiskiem internetowym, równie ważnym jak wspomniane strony WWW, jest poczta elektroniczna (tzw. e-mail) ${ }^{7}$. Jest to najpowszechniejsza dzisiaj forma kontaktu, wypierająca dotychczasowe, tradycyjne formy. Używana jest dziś powszechnie w pracy (uczelnie, korporacje, firmy), ale również w celach prywatnych, pozazawodowych. Jej walorem jest szybkość przekazu oraz brak w praktyce ograniczeń co do ilości (pojemności) przesyłanych informacji. Miarą popularności i znaczenia tej formy kontaktu może być fakt, że trudno dziś wyobrazić sobie wizytówkę bez adresu e-mail.

Kolejny odrębny obszar Internetu stanowią synchroniczne rozmowy (dyskusje) użytkowników (potocznie zwane czatami). Użytkownicy zalogowani w tym samym czasie w sieci mogą prowadzić dialog, który polega na wpisaniu swojej opinii na określony temat (podpisanej zwykle pseudonimem) oraz odczytywaniu pojawiających się na ekranie odpowiedzi przesłanych przez innych użytkowników. Powstają w ten sposób olbrzymie fora dyskusyjne, tzw. pokoje rozmów, (których wyróżnikiem jest zazwyczaj temat rozmowy $)^{8}$, aktywne całą dobę, łączące użytkowników Internetu z całego świata.

Kolejnym bardzo specyficznym obszarem aktywności składającym się na fenomen opisywanego medium są gry komputerowe rozgrywane za pomocą Internetu, tzw. MUD (Multi-User Dungeon) ${ }^{9}$. Scenariusz tego typu gier jest umieszczony na serwerze, do którego może być podłączonych wielu użytkowników w tym samym czasie. Po połączeniu

7 Ibidem.

${ }^{8} \mathrm{Na}$ portalu Onet.pl znaleźć można następujące, przykładowe pokoje rozmów: „,towarzyski”, ,a może zdrada”, ,30 i 40 latki”, „samotni”, ,randka”, ,po rozwodzie”, ,jajcarski pokoik”, „dlaczego by nie”, „nad jeziorem”, „relaks towarzyski”, ,adam szuka ewy", itp. Por. http://czat.onet.pl/1,597,1,3,pokoje.html.

9 Por. np. informacje zawarte na ten temat na stronie internetowej http://pl.wikipedia.org/ wiki/MUD_(RPG). 
gracz wybiera sobie postać, „tworzy ją” i steruje jej zachowaniem przy pomocy zestawu komend tekstowych. Większość MUD-ów toczy się w światach fantasy zasiedlonych przez elfy oraz inne magiczne istoty. Gracze wcielają się w rycerzy, magów i inne typowe dla świata fantasy postaci. Celem gry jest zazwyczaj osiagnięcie odpowiedniego poziomu wtajemniczenia, a postać, rozwiązując zadania (zabijając potwory) zdobywa doświadczenie oraz nowe umiejętności ${ }^{10}$.

Rozwój nowoczesnych technologii informatycznych zaowocował powstaniem nowego jakościowo obszaru aktywności internetowej w postaci tzw. wirtualnych światów (gier typu MMO). Są one dostępnym dla wielu użytkowników trójwymiarowym środowiskiem, ,zamieszkałym" przez stworzone postaci, aktywnym i dynamicznym ${ }^{11}$. Podobnie, jak - mówiąc językiem młodzieżowym - ,w realu", tak również w wirtualnym świecie toczy się wirtualne życie, w którym można uczestniczyć za pośrednictwem swych graficznych wcieleń ${ }^{12}$. Wirtualne światy są multimedialnymi spadkobiercami MUD-ów. Dzięki efektom wizualnym zyskują one znaczące oddziaływanie psychologiczne ${ }^{13}$. Trudno doprawdy przewidzieć, jakie możliwości będzie stwarzał Internet za

10 Szerzej na ten temat por. M. Filiciak, Wirtualny plac zabaw. Gry sieciowe i przemiany w kulturze współczesnej, Warszawa 2006. Najbardziej znanym MUD-em jest LambdaMOO, która powstała w 1991 roku. Znane polskie gry typu MUD to np. „Killer”, „Studnia dusz”, „,Wrota czasu”. Są to typowe gry fantasy, w których użytkownik wciela się w wybraną postać. Np. w grze o nazwie Killer gracz wciela się w przedstawiciela jednej z ras zamieszkujących świat gry. Niektóre rasy preferują zmagania fizyczne i obierają profesję wojowników lub barbarzyńców: są to rasy nazywane w grze półorki i krasnoludy. Pośrednią klasą są paladyni, którymi mogą być jedynie ludzie. Inne „dostępne” rasy to np. elfy, które w grze często obierają drogę kapłaństwa. Szczególne miejsce w grze zajmują magowie, których cechują specyficzne uzdolnienia: mistrz iluzji (specjalista w dziedzinie oszukiwania, omamiania i zwodzenia innych), mistrz zauroczeń (mag potrafiący wpływać na umysły innych, poddając je swojej woli), mistrz przemian (potrafiący zmienić wokół siebie wszystko i wszystkich) czy wreszcie mistrz nekromancji (por. http://pl.wikipedia.org/wiki/Killer).
11 Por. M. Filiciak, op. cit., s. 76 i n.
12 Por. P. Wallace, op. cit., s. 16.
13 Ibidem. 
kilka kolejnych lat. Postęp w tej dziedzinie dokonuje się praktycznie $\mathrm{z}$ roku na rok $^{14}$.

Ta krótka charakterystyka elementów składowych Internetu dobitnie przekonuje, z jak złożonym fenomenem mamy do czynienia. Każdy z wymienionych obszarów czy środowisk Internetu, począwszy od stron WWW po wirtualne światy, oferuje swoim użytkownikom specyficzne możliwości. Każdy z nich również umożliwia zaspokojenie przeróżnych, często specyficznych potrzeb, co nie pozostaje bez wpływu na postawy i zachowania w świecie realnym, szczególnie w przypadku najmłodszych użytkowników sieci.

\section{INTERNET JAKO ZAGROŻENIE}

Problematyka zagrożeń związanych z korzystaniem z komputera i Internetu zaczęła pojawiać się w literaturze po okresie pierwszej fascynacji nowym środkiem przekazu informacji. Zwracano uwagę, że łatwość dostępu do różnego rodzaju treści, połączona $\mathrm{z}$ anonimowością nowego medium i brakiem kontroli nad jego wykorzystaniem, może mieć zgubny wpływ na proces wychowawczy dzieci i młodzieży. Dotychczas miejscem tego procesu była rodzina, wychowawcy (szkoła) oraz różne grupy rówieśnicze. Dzisiaj miejscem tym coraz częściej jest właśnie Internet ${ }^{15}$. Choć wpływ Internetu na dziecko nie jest bezpośrednio przedmiotem zainteresowania w niniejszym artykule, to jednak ze względu na znaczenie tej problematyki i jej związek z tytułowym zagadnieniem, błędem byłoby pominięcie tego problemu, tym bardziej, że obecnie rodziny zakłada pokolenie, które zetknęło się z Internetem $w$ wieku bardzo wczesnym i w sensie właściwym może

${ }^{14}$ Coraz większą popularnością cieszą się również tzw. blogi czyli internetowe pamiętniki, choć nie stanowią one odrębnego środowiska internetowego. Warto jednak o nich wspomnieć, choćby ze względu na ich popularność czy panującą modę. Blogi często przybierają postać komentarzy do bieżących wydarzeń społecznych czy politycznych. Z uwagi na fakt, że są ogólnie dostępne, stają się źródłem wielu ciekawych informacji, wykorzystywanych w innych mediach.

15 Por. P. KwIATKowski, Internet jako nowe narzędzie zaspokajania potrzeb przez adolescentów, [w:] Człowiek u progu trzeciego tysiaclecia. Zagrożenia $i$ wyzwania, I, pod red. M. Plopy, Elbląg 2005, s. 470 i n. 
być nazwane pokoleniem sieci. W praktyce zatem przypadki zawierania małżeństw przez osoby już uzależnione od Internetu mogą występować równie często, jak przypadki uzależnienia się w trakcie trwania małżeństwa.

Zagrożenia płynące z Internetu w odniesieniu do dziecka można ująć generalnie w trzy grupy: zagrożenia związane z treścią informacji zawartych w Internecie, sposobem komunikowania się oraz czasem przeznaczanym na Internet ${ }^{16}$. Szczególnie niebezpieczne, wydają się przy tym zagrożenia związane z pierwszą z wymienionych grup treścią danych dostępnych w Internecie. Dotyczy to przede wszystkim treści o charakterze pornograficznym. Łatwowierność dziecka w kontaktach z osobami obcymi, anonimowość internetowych relacji oraz brak kontroli ze strony rodziców może prowadzić nawet do seksualnego wykorzystania dziecka ${ }^{17}$. Wśród zagrożeń specjalne miejsce zajmują gry komputerowe (także internetowe), szczególnie pewien ich rodzaj emanujący rywalizacją i agresją, które - jak przekonują wyniki badań - destrukcyjnie wpływają na psychikę dziecka ${ }^{18}$. Świat gier i wirtualnej rzeczywistości alienuje do tego stopnia, że zanika potrzeba bezpośredniego kontaktu z drugą osobą. Relacja, jaką tworzy świat wirtualny, wypiera relacje interpersonalne ${ }^{19}$. Jeśli dotyczy to dziecka, prawdopodobieństwo występowania trudności w nawiązywaniu trwałych relacji (w krańcowych przypadkach można nawet mó-

16 Por. M. Braun-GatKowska, Oddziatywanie Internetu na psychike dzieci i młodzieży. [w:] Dziecko a Internet. Szanse-zagrożenia. Materiaty z konferencji naukowej. Warszawa 9 grudnia 2002, http://www.brpd.gov.pl/dzieckoainternet.html.

17 Por. L. Mendelka, Internet a wykorzystanie seksualne dziecka, [w:] Oblicza Internetu, pod red. M. Sokołowskiego, Elblag 2004, s. 281-291. Autorka wymienia następujące, główne formy seksualnego wykorzystywania dziecka w Internecie: prezentowanie materiałów pornograficznych, produkcja i prezentowanie pornografii dziecięcej, wykorzystywanie serwisów internetowych przez pedofilów w celu kontaktu z potencjalnymi ofiarami (ibidem, s. 282).

18 Szerzej na ten temat por. M. Braun-GaŁkowska, I. Ulik-Jaworska, Zabawa w zabijanie, Lublin 2002, szczególnie s. 97-161.

19 Por. J. Boroń, T. ZYss, Świat gier komputerowych II - badania ankietowe nad ich rozpowszechnieniem wśród młodzieży szkót średnich, «Psychiatria Polska»30, s. $267 \mathrm{i} \mathrm{n}$. 
wić o niezdolności ich nawiązania), które zakładają zdolność empatii i „wyjścia poza siebie” jest bardzo duże, większe niż w przypadku osobowości w pewnym stopniu już ukształtowanych. ${ }^{20}$

Internet, jak żadne inne znane narzędzie komunikacji, stwarza także doskonałe pole do eksperymentowania $\mathrm{z}$ własną tożsamością ${ }^{21}$. Użytkownik, szczególnie w obszarze gier, może przybierać dowolną płeć, wiek, rasę, itp. i „sprawdzać” wrażenie, jakie wywarł na innych graczach. Jest to szczególnie niebezpieczne w odniesieniu do najmłodszych użytkowników sieci, których tożsamość i właściwe jej cechy osobowości są w fazie kształtowania się. Jeżeli nastolatek nie znajduje uznania i akceptacji w życiu realnym, a odnajduje je w sferze wirtualnej dzięki zabiegom nad własną tożsamością, tym bardziej będzie poszukiwał kontaktu z Internetem. To z kolei może z pewnością utrudnić (albo wręcz uniemożliwić) naturalny proces samoakceptacji, a ponadto grozi szybkim uzależnieniem się od sieci. Społeczne skutki opisywanego procesu są bardzo szkodliwe. Prowadzą np. do rozwodogennej sytuacji już w momencie zawierania małżeństwa. Osoba uzależniona nie jest zdolna do podjęcia normalnego pożycia, stworzenia właściwej wspólnoty małżeńskiej i rodzinnej. Problem ten będzie rozwinięty w dalszej części artykułu.

Rozwój Internetu „zaowocował' również powstaniem nowej niespotykanej wcześniej subkultury młodzieżowej - tzw. hakerów, określanych także mianem przestępców cyberprzestrzeni ${ }^{22}$. Co ciekawe, zmienia się profil psychologiczny nastolatków przejawiających tego typu zachowania. Hakerstwo, jak twierdzi P. Kwiatkowski, przestało być formą kompensacji zarezerwowaną dla wybranych, a staje się dla co raz liczniejszej grupy nastolatków sposobem autokreacji. ${ }^{23}$.

${ }^{20}$ Nie wszyscy autorzy dostrzegają niebezpieczeństwo, o którym mowa. Np. dla M. FILICIAKA, op. cit., s. 69 i n. ,gra jest rodzajem symulacji, przygotowującej dzieci do pełnienia w przyszłości np. ról społecznych".

21 Por. P. KwiatKowski, op. cit., s. 472.

22 Por. J. BorzęCKA, Hakerzy - uzależnienie czy subkultura młodzieżowa?, [w:] Uzależnienia a rodzina. Wybrane zagadnienia, pod red. R. DomżAŁ-DrzeWickieJ, A. ŚCIBOR, H. KaźmieraK, Lublin 2008, s. 143-147.

23 Por. P. Kwiatkowski, op. cit., s. 473. 
Ukazane powyżej w sposób ogólny zagrożenia związane z korzystaniem z Internetu nie są w sposób konieczny związane z uzależnieniem od niego, choć z pewnością fakt uzależnienia lub przynajmniej nadmiernego używania analizowanego medium potęguje te wszystkie zagrożenia. Możliwość uzależnienia od Internetu stanowi w porównaniu z opisanymi zagrożeniami pewną nową jakość. Jest to bez wątpienia również jedno z zagrożeń związanych z Internetem, a zarazem swoiste podłoże, na którym rodzą się nieakceptowane i patologiczne zachowania.

\section{INTERNET JAKO PRZEDMIOT UZALEŻNIENIA}

Obserwowany na przestrzeni ostatnich lat olbrzymi postęp technologiczny, obok niewątpliwych i niekwestionowanych wartości i jeszcze większych nadziei, niesie z sobą również, jak wyżej wskazano, poważne zagrożenia. Zasadnicze z nich dotyczy wpływu tej technologicznej i informatycznej rewolucji na osobowość człowieka i tworzone przez niego więzi społeczne. Widocznym skutkiem dokonujących się zmian są nowe formy uzależnień oraz wzrost liczby osób wykazujących znamiona uzależnienia. Pojęciem nowych uzależnień określa się istniejące obecnie uzależnienia, w których substancje chemiczne (np. alkohol, rodzaj narkotyku) nie odgrywają decydującej roli. C. Guarreschi do grupy tej zalicza między innymi: uzależnienie od telefonu komórkowego, uzależnienie od zakupów oraz, przede wszystkim, uzależnienie od Internetu ${ }^{24}$. W literaturze dotyczącej omawianej problematyki funkcjonuje także bardziej generalne określenie - uzależnienie od elektronicznych środków przekazu - obejmujące uzależnienie od telewizora, komputera, telefonu, automatu do gier, itp. ${ }^{25}$

24 Por. C. Guarreschi, Nowe uzależnienia, Kraków 2006. Wśród tzw. nowych uzależnień autor wymienia także uzależnienie od seksu, od pracy oraz tzw. uzależnienie emocjonalne.

25 Por. I. Pospiszyl, Patologie społeczne, Warszawa 2008, s. 186. Omawiając uzależnienia, Autorka odrębny podrozdział poświęca hazardowi, jako coraz częściej występującemu dziś i niebezpiecznemu uzależnieniu, ibidem, s. 197 i n. 


\section{A. Pojęcie uzależnienia od Internetu i jego kryteria}

W literaturze przedmiotu spotkać można sformułowanie „Internet Addiction Disorder" (IAD) rozumiane jako uzależnienie (zaburzenie) przejawiające się w sposobie korzystania z nowego produktu technologicznego ${ }^{26}$. Angielski termin ,addiction” (w przeciwieństwie do „dependence") oznacza uzależnienie psychologiczne, które zmusza do poszukiwania przedmiotu uzależnienia ${ }^{27}$. Osoba dotknięta tym zaburzeniem spędza długie godziny przed komputerem, zaniedbując swe obowiązki. Nie potrafi ona kontrolować potrzeby „bycia w sieci” i przeżywa frustrację z powodu niemożności zaspokojenia swej potrzeby. Ten bardzo ogólny jeszcze obraz kliniczny uzasadnia, zdaniem części psychologów, postulat stworzenia nowej kategorii diagnostycznej, opisującej patologiczne korzystanie $\mathrm{z}$ Internetu ${ }^{28}$.

Jednym z pionierów w tym obszarze badań jest I. Goldberg, który przedstawił kryteria rozpoznawania uzależnienia od Internetu. Zaistnienie przynajmniej trzech z wymienionych przez Goldberga kryteriów w ciagu jednego roku, oznacza - jego zdaniem - popadnięcie w uzależnienie. Pierwszym z tych kryteriów jest potrzeba co raz dłuższego korzystania z Internetu w celu uzyskania satysfakcji, z jednoczesnym jej spadkiem przy niewydłużaniu czasu „bycia w sieci”29.

${ }^{26}$ Por. C. GuArreschi, op. cit., s. 33.

27 Ibidem.

28 Postulat ten ma również swych przeciwników. Na przykład J.M. Grohol twierdzi, że nadmiernie używanie Internetu jest po prostu formą ucieczki od głębszych problemów życiowych, podobnie zresztą jak ma to miejsce w przypadku oglądania telewizji, ucieczki w pracę czy jakakolwiek inną czynność, za którą chronimy się, nie chcąc stawić czoła rzeczywistemu problemowi. Tego typu postawy i związane z nimi tzw. zachowania kompulsywne (natręctwa) są częścią ogólniejszych kategorii diagnostycznych, w terapii których bazuje się na założeniu, że środki technologiczne nie są odpowiedzialne za powstanie uzależnień (por. C. GUARrEschi, op. cit., s. 34-35; por. także A. JAKUBIK, op. cit., s.136-137).

${ }^{29}$ Kryterium to określane jest w literaturze mianem tolerancji. Por. np. K. Young, P. Klausing, Uwolnić się z sieci. Uzależnienie od Internetu, Katowice 2009. Pojęcie tolerancji jest wieloznaczne i może być różnie rozumiane. W kontekście, o którym mowa, jest niezrozumiałe dla przeciętnego czytelnia, czego dowodem jest fakt, że 
Innymi słowy, „,apetyt rośnie w miarę jedzenia”. Uzależniony potrzebuje coraz dłuższego kontaktu z siecią celem odczuwania określonego poziomu satysfakcji, chociaż początkowo pojawiała się ona dużo wcześniej (w krótszym czasie). Druga grupa kryteriów związana jest $\mathrm{z}$ tzw. syndromem odstawienia, tzn. funkcjonowania przez dłuższy czas poza siecią. Oznaką uzależnienia w takiej sytuacji byłyby, zdaniem Goldberga, następujące objawy: pobudzenie psychoruchowe, lęk, obsesyjne myślenie o Internecie, fantazje i sny na jego temat oraz mimowolne, niekontrolowalne ruchy palców (tak, jak podczas pracy na klawiaturze). Potwierdzeniem stanu uzależnienia byłby również powrót do korzystania z przedmiotu uzależnienia, jedynie w celu uniknięcia wymienionych symptomów, wskazujących na uzależnienie. Trzecia grupa kryteriów odnosi się do sfery przystosowania społecznego. W grupie tej można wyróżnić następujące zachowania przemawiające za uzależnieniem: Ograniczenie innych form aktywności społecznej czy zawodowej (także rekraacyjnej) spowodowane potrzebą korzystania z Internetu, nieudane próby ograniczenia korzystania z Internetu lub autokontroli, korzystanie z Internetu pomimo świadomości problemu i narastających dolegliwości z nim związanych, zarówno indywidualnych (fizycznych), jak i społecznych - np. problemów w kontaktach z najbliższymi i otoczeniem ${ }^{30}$. Te właśnie zachowania, jako skutki uzależnienia od Internetu wydają się najbardziej niepokojące, a pierwszym środowiskiem, które doświadcza ich destrukcyjnego działania jest najczęściej rodzina.

Problem uzależnienia od Internetu podjęła w swych badaniach również K. Young. Autorka ta uważana jest powszechnie za jednego z najlepszych znawców omawianego problemu. Young, na podstawie prowadzonych badań, wyróżnia pięć typów uzależnienia związanego

tłumacz uznał za stosowne, celem właściwego zrozumienia tekstu, zawrzeć w przypisie wyjaśnienie tego pojęcia. Tolerancja, jego zdaniem, to „zdolność przystosowania organizmu do obecności jakiejś substancji lub podejmowania jakiejś aktywności w większym wymiarze" (por. też s.15 przyp. 6). Może warto byłoby jednak poszukać bardziej adekwatnego i nie budzącego wątpliwości pojęcia dla opisania omawianego kryterium.

30 Por. C. Guarreschi, op. cit., s. 38-39. 
z komputerem: erotomanię internetową, uzależnienie od internetowych kontaktów społecznych, uzależnienie od sieci internetowej, uzależnienie od komputera oraz przeciążenie informacyjne - przymus pobierania informacji ${ }^{31}$. Zdaniem Young, z uzależnieniem od Internetu mamy do czynienia w przypadku wystąpienia przynajmniej pięciu z ośmiu podanych przez nią kryteriów: Kryteriami tymi są:

1. niepokój związany z Internetem,

2. narastająca potrzeba spędzania czasu online,

3. powtarzające się próby ograniczenia czasu korzystania z Internetu,

4. zamykanie się $\mathrm{w}$ sobie $\mathrm{w}$ sytuacji ograniczonego korzystania z Internetu,

5. problemy z planowaniem czasu,

6. problemy związane ze stresem w rodzinie, szkole, pracy, wśród przyjaciól, wywołane czasem korzystania z Internetu,

7. okłamywanie innych na temat ilości czasu spędzanego w Internecie,

8. zmiany nastroju. ${ }^{32}$

Na polskim gruncie koncepcję kryteriów uzależnienia, w nawiązaniu do prac Goldberga, opracował B. T. Woronowicz ${ }^{33}$. Siecioholizm tak autor określa analizowane uzależnienie - zachodzi wówczas, gdy u użytkownika Internetu w ciagu minionych 12 miesięcy wystąpily przynajmniej trzy z następujących jego znamion: silna potrzeba lub odczuwanie przymusu korzystania z Internetu, subiektywne przekonanie o mniejszej możliwości kontrolowania korzystania z Internetu, występowania tzw. objawów odstawienia (niepokoju, rozdrażnienia czy gorszego samopoczucia podczas prób ograniczenia kontak-

31 Por. K. Young, What is Internet Addiction?, www.addicted.com/addictionprofessionals/kimberly-young. H. Ginowicz dodaje do tego katalogu także: stałe porządkowanie komputera (plików, aplikacji, tzw. defragmentacja dysku), ustawiczne ulepszanie parametrów technicznych komputera oraz obsesyjne łamanie kodów zabezpieczających komputery i hakerstwo (por. H. Ginowicz, Zagrożenia płynqce z sieci, «Terapia Uzależnienia i Współuzależnienia» 2003 nr 1, s. 19).

32 Por. K. Young, op. cit.

33 Por. B. T. Woronowicz, Bez tajemnic o uzależnieniach i ich leczeniu, Warszawa 2001, s. 193 i n. 
tu z Internetem), wydłużanie czasu bycia w sieci celem osiagnięcia oczekiwanego poziomu satysfakcji oraz ostatnie kryterium - stałe korzystanie z Internetu pomimo zaistnienia jego negatywnych następstw (fizycznych, psychicznych i społecznych) ${ }^{34}$.

W opisanych pokrótce koncepcjach dotyczących kryteriów (znamion) uzależnia można dostrzec pewne istotne cechy wspólne. Wśród proponowanych kryteriów rozpoznawania uzależnienia pojawiają się zachowania, dotyczące odniesień społecznych analizowanej formy uzależnienia - problemy w relacjach, szczególnie w rodzinie, znamionujące postępującą alienację uzależnionego. Warto kryterium to wyeksponować, gdyż wydaje się, że stanowi ono swoisty „papierek lakmusowy" lub zewnętrzny obiektywny weryfikator rzeczywistego problemu osobistego. Jeśli, mówiąc potocznie, coś dzieje się z człowiekiem, to najszybciej zauważą lub odczują to najbliżsi i będzie to zarazem kryterium obiektywizujące dane zjawisko.

\section{B. Fazy i formy uzależnienia od Internetu}

Obok kryteriów rozpoznawania uzależnienia, w literaturze analizuje się również fazy uzależnienia. Nie ulega wątpliwości, że każda choroba, także uzależnienie (bez względu na przedmiot), rozwija się stopniowo, ma pewne fazy. Scenariusz rozwoju uzależnienia jest zwykle bardzo podobny. W literaturze wymienia się zazwyczaj cztery podstawowe fazy uzależnienia ${ }^{35}$ :

1. Zaangażowanie - cechuje je okazjonalne korzystanie z Internetu, poznawanie go. Faza ta charakteryzuje się również posługiwaniem się komputerem w ściśle określonym celu: odbieranie poczty, wykonywanie określonego zadania, itp. Faza ta sama w sobie nie stanowi oczywiście uzależnienia, nie wpływa również na pogorszenie relacji zawodowych czy rodzinnych.

2. Zastępowanie - korzystanie z komputera (Internetu) staje się regularne, a czas poświęcany na inne zajęcia jest ograniczany. Fazę tę ce-

34 Ibidem.

35 Por. I. Pospiszyl, op. cit., s. 192. 
chują między innymi postawa użytkownika polegająca na surfowaniu po Internecie bez określonego celu (ani praca, ani relaks) oraz pierwsze objawy izolacji społecznej. W fazie tej, jak się podkreśla, użytkownik Internetu zaczyna przedkładać kontakt bezosobowy nad relacje personalne (osobowe), w tym także, a nawet przede wszystkim, rodzinne. Może to powodować, i zwykle powoduje, pierwsze poważne nieporozumienia między małżonkami, gdyż postawa taka wiąże się integralnie z zaniedbywaniem obowiązków - najpierw rodzinnych, później zawodowych.

3. Ucieczka - właściwe tej fazie dezorganizacja rytmu dnia i nagminne zaniedbywanie zajęć powodują stałe problemy z bliskimi. Pojawiają się mechanizmy wyparcia problemu oraz postawa ukrywania uzależnienia - kłamstwa, nieuczciwości, półprawdy, a jednocześnie stale rosnąca potrzeba korzystania z komputera jako środka pozwalającego zapomnieć o problemach. Świat wirtualny zastępuje świat rzeczywisty. Odnosząc do omawianego problemu kategorie prawnorodzinne, należałoby powiedzieć, że w fazie tej rozkład pożycia między małżonkami jest daleko posunięty.

4. Desperacja - ostatnia faza, którą cechuje gwałtowna próba powrotu do normalności, wywołana zwykle okolicznościami zewnętrznymi. Okolicznościami tymi mogą być np. faktyczna separacja, rozwód, a także pozbawienia władzy rodzicielskiej w wyniku rażących zaniedbań w stosunku do osoby dziecka. Uzależniony - co jest również typowe dla tej fazy - przestaje stosować już mechanizmy obronne i szuka pomocy. Powrót do normalności, a zwłaszcza odbudowa relacji rodzinnych, zniszczonych przez uzależnienie, jest bardzo długim i złożonym procesem, a ponadto nie zawsze jest możliwa. Nawet jeżeli będzie ona uwieńczona sukcesem, to trzeba zdawać sobie sprawę z trwałych skutków, które opisywana sytuacja może pozostawić i które mogą rzutować na jakość dalszego pożycia. ${ }^{36}$

Internet jest, jak wspomniano, przestrzenią wielowymiarową, łączy w sobie wiele środowisk. Również uzależnienie od niego może przybierać różne formy. Jedną z najczęściej pojawiających się w bada-

36 Ibidem. 
niach jest uzależnienie od wirtualnego seksu ${ }^{37}$. Pojęciem tym opisuje się czynności bądź zachowania, których celem jest wywołanie podniecenia seksualnego. Wyrażają się one zazwyczaj poprzez: oglądanie (ściaganie) stron o tematyce pornograficznej, odwiedzanie czatów erotycznych, prowadzenie korespondencji elektronicznej w celu znalezienia partnera seksualnego, co może przerodzić się w rzeczywiste kontakty seksualne poza siecią ${ }^{38}$. W przeciwieństwie do „klasycznych” sposobów zaspokajania potrzeb o charakterze seksualnym (czasopisma, kino, domy publiczne, itp.), Internet posiada wiele cech, które czynią go wprost idealnym „miejscem” tego typu aktywności. Łatwy, stosunkowo tani i legalny dostęp do niego, anonimowość, możliwość korzystania w domowym zaciszu, bez większego ryzyka - wszystko to niewatpliwie wpływa na popularność tzw. seksu wirtualnego. Jego popularność stale rośnie i w wielu przypadkach wypiera tradycyjne formy. W psychologii znana jest teoria tzw. superbodźca, ${ }^{39}$ zgodnie z którą, stopień reakcji podmiotu zależy od stopnia atrakcyjności przedmiotu, np. superfigury, śmiałej sceny erotycznej, obrazu, itp. Seks wirtualny składa się z niezliczonej ilości takich superbodźców. Cechuje go ponadto wprost nieograniczona zmienność i selektywność ${ }^{40}$. Podczas jednego zachowania seksualnego w sieci, użytkownik może wykorzystywać w celu wprowadzenia się w stan podniecenia wiele bodźców (powtarzanie scen, przybliżanie, oddalanie, nowe obiekty, itp.). Nietrudno wyobrazić sobie, jakie skutki pociaga za sobą opisywana forma uzależnienia od Internetu w odniesieniu do związków małżeńskich (także konkubinatów). Rzeczywisty partner (małżonek) jest, w porównaniu z dostępnymi za pomocą Internetu superbodźcami, zwykle na straconej pozycji. Seks rzeczywisty w obliczu „bogactwa”

37 Por. C. Guarreschi, op. cit., s. 64 in. Na temat nowych możliwości „wzbogacania” doświadczeń seksualnych, dostępnych dzięki rozwojowi elektroniki, por. J. PAPIEż, Cyberprzestrzeń a doznawanie przeżyć erotycznych. [w:] Oblicza Internetu, cit., s. $263 \mathrm{i} \mathrm{n.}$

38 C. Guarreschi, op. cit., s. 70.

39 Por. W. Ślusarz, Aktywność seksualna w Internecie. Aspekty psychologiczne. [w:] Oblicza Internetu, cit., s. 273 i n.

40 Ibidem, s. 277. 
Internetu w omawianym zakresie, staje się dla wielu nudny, nieciekawy, często stresujący, co jeszcze bardziej wiąże użytkownika Internetu ze światem wirtualnym ${ }^{41}$.

Największym jednak niebezpieczeństwem, związanym z omawianym rodzajem uzależnienia od Internetu, jest apersonalizacja zachowań seksualnych. Partner fizyczny staje się po prostu niepotrzebny. To, co do niedawna stanowiło integralny $\mathrm{i}$ istotny element pożycia i konsolidacji związku, zostaje zastapione odniesieniem do obiektu wirtualnego. Postawa taka w prostej linii, wcześniej czy później, prowadzi do rozkładu pożycia i rozwodu. Poprzedzony on jest przy tym, co łatwo sobie wyobrazić, konfliktami, w których biernie (a często aktywnie) uczestniczą także dzieci. Podkreślić należy również, że - podobnie, jak w przypadku klasycznych nałogów czy uzależnień, np. alkoholizmu - uzależnienie jednego członka rodziny wywołuje zwykle efekt współuzależnienia ${ }^{42}$. W literaturze wyróżnia się trzy stadia, przez które przechodzi osoba współuzależniona (współmałżonek uzależnionego $)^{43}$. Stadium pierwsze cechuje nieświadomość faktu uzależnienia i problemów z nim związanych. Odpowiedzialność za pogorszenie relacji, współmałżonek przypisuje sobie, stara się zazwyczaj zwiększyć swą atrakcyjność. Stadium drugie - to odkrycie uzależnienia i związany z tym swoisty szok, jaki przeżywa współmałżonek. Odkrycie faktu uzależnienia następuje albo przypadkowo, albo w wyniku pewnych świadomych działań, które podejmuje współmałżonek zaniepokojony pogarszaniem się jakości pożycia. Stadium to charakteryzuje się silnymi emocjami i ich biegunowością - od zagubienia i wstydu aż po wściekłość i gniew ${ }^{44}$. Małżonkowie oddalają się od siebie, żyją również w izolacji, gdyż rozmowa o tego typu problemie z osobami trze-

41 Ibidem.

42 Szerzej na ten temat por. np. I. PosPiszYL, op. cit., s. 153-157.

43 Por. C. Guarreschi, op. cit., s. 75 i n.

44 Por. K. Young, P. Klausing, op. cit., s. 113 i n. Autorki cytują słowa jednej z kobiet korzystających z terapii, której mąż był uzależniony od seksu wirtualnego: „Nie mogę wprost uwierzyć, że są we mnie takie uczucia. Nigdy nie żywiłam do nikogo nienawiści, nigdy nie odczuwałam potrzeby, aby coś zniszczyć. A tymczasem teraz chciałam rozwalić jego komputer na kawałki”. 
cimi jest bardzo trudna i wstydliwa. Stadium trzecie opisywane jest jako próba rozwiązania problemu. Współmałżonek stara się podjąć jakieś działania, które mogłyby pomóc uzależnionemu i ratować związek, np.: persfazja, kontrola dostępu do sieci, poszukiwanie informacji o problemie, zwiększenie częstotliwości współżycia w nadziei, że małżonek straci zainteresowanie Internetem. C. Guarreschi twierdzi ${ }^{45}$, że zachowania takie dają współuzależnionemu małżonkowi iluzoryczne poczucie kontrolowania sytuacji. W rzeczywistości zachowania te prowadzą do wytworzenia w związku relacji rodzic - dziecko, którą cechuje niedojrzałość i nieszczerość.

Wśród form uzależnienia od Internetu wymienia się również uzależnienie od relacji wirtualnych. Definiowane jest ono jako potrzeba nawiązywania stosunków przyjacielskich lub intymnych za pomocą Internetu $^{46}$. Służą temu poczta elektroniczna, tzw. czaty i inne fora dyskusyjne. Forma ta, podobnie jak omówiona powyżej, prowadzić może do osłabienia a nawet rozpadu rzeczywistych więzi (małżeńskich). Jej konsekwencją może być bowiem powstanie między jednym z małżonków a osobą trzecią z Internetu (lub grupą osób) bliższej (głębszej) relacji, niż istniejąca między małżonkami. Im bliższa relacja, tym silniejsze „ciążenie” w jej kierunku, co z kolei wiąże się z osłabieniem lub ustaniem innych relacji. W odniesieniu do małżeństwa sytuacja taka objawia się zaniedbywaniem małżonka i rodziny najpierw poprzez bagatelizowanie obowiązków o charakterze niemajątkowym (brak troski o jakość pożycia, wzajemną pomoc), a z czasem także majątkowych (zaspokajania potrzeb rodziny).

Wśród zagrożeń, które wiążą się z wykorzystywaniem Internetu i destrukcyjnie oddziałują na rodzinę wymienia się również tzw. net complusions $^{47}$ - różne formy zachowań obsesyjnych związanych z hazardem, czynnym udziałem w licytacjach czy też handlem. Zachowania te mają wiele cech wspólnych - poza faktem, że są dostępne przez Internet, zawierają element ryzyka, a ich uprawianie może być ekscytu-

\footnotetext{
45 C. Guarreschi, op. cit., s. 76.

46 Ibidem, s. 78 i n.

47 Ibidem, s. 80 i n.
} 
jące. K. Young opisuje jeden z przypadków, w którym uzależnienie od hazardu i zakupów spowodowało rozpad małżeństwa ${ }^{48}$. Przypadków takich może być z pewnością więcej, gdyż ta forma uzależnienia nie ogranicza się, jak mogłoby się wydawać, tylko do sfery majątkowej rodziny. Od niej się zwykle zaczyna, a kończy się na utracie zaufania współmałżonka, co prowadzi do rozkładu wzajemnego pożycia i rozwodu.

$\mathrm{Z}$ tej krótkiej prezentacji form uzależnienia od Internetu i ich skutków, jednoznacznie wynika z jak negatywnym zjawiskiem mamy do czynienia. Zarówno indywidualne, jak i społeczne skutki uzależnienia od Internetu domagają się szybkiej reakcji społeczeństwa. Pewne konkretne propozycje $\mathrm{w}$ tym zakresie przedstawione zostaną we wnioskach.

\section{UZALEŻNIENIE OD INTERNETU I JEGO WPŁYW NA ROZKŁAD POŻYCIA W ŚWIETLE BADAŃ ANKIETOWYCH}

Celem rozważań tej części artykułu jest prezentacja wyników badań ankietowych dotyczących uzależnienia od Internetu jako przyczyny rozkładu pożycia małżeńskiego ${ }^{49}$.

\section{A. Metodologia badań i hipotezy badawcze}

Badania, których wyniki są przedmiotem analizy, zostały przeprowadzone na grupie 120 respondentów. Struktura badanej grupy osób przedstawiała się następująco: $25 \%$ ankietowanych osób żyło w związkach małżeńskich, kolejne $25 \%$ - w tzw. związkach nieformalnych, a pozostali ankietowani (50\%) byli rozwiedzeni. Spośród badanych $65 \%$ nie przekroczyło jeszcze 25 roku życia, natomiast $13 \%$ znajdowało się w przedziale wiekowym między 31-36 lat. Jedynie 7 osób spośród 120

48 Por. K. Young, P. Klausing, op. cit., s. 120 i n.

49 Badania te zostały przeprowadzone przez Ewę Turewicz i zamieszczone w pracy magisterskiej zatytułowanej: „Uzależnienie od Internetu jako przyczyna rozkładu pożycia małżeńskiego", napisanej pod moim kierunkiem i obronionej na Wydziale Prawa i Administracji Uniwersytetu Kardynała Stefana Wyszyńskiego w Warszawie w roku akademickim 2007/2008 (por. www.apd.usos.uksw.edu.pl). W niniejszym artykule wykorzystano jedynie wyniki tych badań. 
(5,6\%) badanych przekroczyło 37 rok życia. Byli to zatem w zdecydowanej większości ludzie bardzo młodzi. Ponad połowa badanych (61\%) pochodziła z dużych miast (ponad 50 tys. mieszkańców), w tym $42 \%$ z miast liczących ponad 200 tys. mieszkańców. Wszystkie osoby objęte badaniem miały dostęp do Internetu. Narzędziem badawczym był formularz ankiety rozesłany do respondentów za pomocą poczty elektronicznej (w nielicznych przypadkach były to formularze wydrukowane), składający się z trzech merytorycznych części.

Przystępując do badania sformułowano m.in. następujące hipotezy badawcze:

1. Uzależnienie od Internetu może powodować rozkład pożycia małżeńskiego.

2. Zjawisko uzależnienia od Internetu występuje głównie u osób, których praca wiążę się z komputerem.

3. Uzależnienie od Internetu wpływa negatywnie na więzi łączące małżonków.

4. Uzależnienie od Internetu ujemnie wpływa na zachowanie obowiązku wierności.

B. Analiza wyników badań i weryfikacja hipotez badawczych

Pierwsza część ankiety dotyczyła zapatrywań respondentów na temat wpływu uzależnienia od Internetu na relacje między małżonkami i ich wspólne pożycie. Na pytanie „Jak określił(a)by Pan/i wpływ Internetu na pożycie małżeńskie?”, 49\% badanych odpowiedziało „,negatywny”, $36 \%$ respondentów - „pozytywny”, a 12\% wybrało wariant neutralny (Internet nie ma ani negatywnego, ani pozytywnego wpływu na pożycie). Tylko 7\% badanych nie miło zdania na ten temat. Odpowiedzi na kolejne pytania dostarczyły następujących informacji: Zdecydowana większość ankietowanych (66\%) była przekonana, że nadmierne korzystanie z Internetu może powodować zaniedbywanie obowiązków domowych. Również zdecydowana większość (77\%) ankietowanych wyraziła pogląd, że „nadmierne korzystanie z Internetu jest przyczyną kłótni między małżonkami”. Wśród respondentów, którzy wyrazili taki pogląd, większość stanowiły osoby rozwiedzione. Szczególne istotne 
wydaje się określenie wpływu uzależnienia od Internetu na więzi łączące małżonków, zwłaszcza więzi mające wpływ na jakość wspólnego pożycia (więź duchowa, fizyczna i gospodarcza) ${ }^{50}$. Zdaniem $72 \%$ badanych uzależnienie od Internetu (lub nadmierne korzystanie z niego) pogarsza relacje fizyczne między małżonkami, zaś zdaniem $62 \%$ negatywnie wpływa na więź duchową. Co ciekawe, większość mężczyzn opowiedziała się za negatywnym wpływem uzależnienia od Internetu na więź fizyczna, podczas gdy większość kobiet podkreślała negatywne skutki uzależnienia w odniesieniu do więzi duchowej. Większość respondentów (78\%) nie dostrzega natomiast negatywnego wpływu uzależnienia od Internetu na więź gospodarczą. Nasuwa się wniosek, że zagrożenie jakie powoduje uzależnienie od Internetu odnosi się - zdaniem respondentów - przede wszystkim do więzi fizycznej i duchowej pożycia. Wniosek ten znajduje potwierdzenie w odpowiedzi na kolejne pytanie, które brzmiało: „Czy uważa Pan/i, że nadmierne korzystanie z Internetu może wpływać na dochowanie wierności partnerowi”. Aż 73\% ankietowanych udzieliło odpowiedzi twierdzącej. Żaden z respondentów - co należy w tym miejscu szczególnie podkreślić - nie udzielił na ww. pytanie odpowiedzi przeczącej, która negowałaby istnienie związku między nadużywaniem Internetu a dochowaniem obowiązku wierności. Opisany w pierwszej części artykułu na podstawie opracowań naukowych związek między uzależnieniem od Internetu a fizyczną więzią łączącą małżonków, potwierdzają wyniki badań empirycznych. Budzi przy tym poważne zaniepokojenie skala zjawiska. Dla ponad $70 \%$ ankietowanych związek między uzależnieniem od Internetu a więzią fizyczną małżonków jest oczywisty, co nie znajduje jednak należnego odzewu społecznego i nie wywołuje stosownej reakcji społeczeństwa.

Swoistym zwieńczeniem pierwszej części ankiety było pytanie, „czy uzależnienie od Internetu może być przyczyną rozwodu?”. Aż $80 \%$ ankietowanych udzieliło dopowiedzi twierdzącej. Uzyskany wynik jest

${ }^{50}$ Tak właśnie jako sumę trzech wymienionych w tekście więzi, postrzega obowiązek wspólnego pożycia orzecznictwo. Por. Uchwała Całej Izby Cywilnej SN z dnia 28 maja 1955 r. («OSN» $1955 \mathrm{nr} 3$, poz. 46), Wytyczne wymiaru sprawiedliwości i praktyki sądowej w zakresie stosowania art. 29 k.r. 
dobitnym potwierdzeniem danych dotyczących wpływu uzależnienia od Internetu na pożycie małżonków, szczególnie na więź fizyczną i obowiązek wierności. Warto przytoczyć w tym miejscu także opinie respondentów na temat badanego zjawiska. Jeden z respondentów stwierdził: „Uważam, że problem uzależnienia od Internetu jest bardzo popularny, tylko bagatelizowany i z uwagi na potrzebę korzystania z komputera wszędzie, niedoceniany i nie leczony." Inny z respondentów zauważył: „Internet wpływa w szczególności na pożycie lub jego brak, bo jak się siedzi przed komputerem, to nie ma czasu na sex."

Podsumowując krótko tę część ankiety należy stwierdzić, że uzależnienie od Internetu jest postrzegane przez respondentów jako rzeczywiste zjawisko. Będąc przyczyną nieporozumień i konfliktów między małżonkami oraz zaniedbywania domowych obowiązków, ma negatywny wpływ na ich wzajemne pożycie i w konsekwencji prowadzi do rozwodu.

Celem drugiej części przedmiotowej ankiety było uzyskanie informacji na temat częstotliwości korzystania z Internetu przez respondentów. W szczególności chodziło o zbadanie, czy wśród ankietowanych występują osoby wykazujące znamiona uzależnienia od Internetu. Pierwsze pytanie $\mathrm{w}$ tej części ankiety dotyczyło czasu korzystania z Internetu. Ponad połowa badanych osób (61\%) stwierdziła, że spędza $\mathrm{w}$ Internecie tygodniowo ponad 50 godzin, przy czym dla $12 \%$ $\mathrm{z}$ tej grupy respondentów, czas korzystania $\mathrm{z}$ niego przekracza w ciągu tygodnia 63 godziny. Dla $22 \%$ badanych osób tygodniowy czas spędzany w Internecie waha się między 36 a 49 godzin, zaś w przypadku $19 \%$ ankietowanych, nie przekracza on 35 godzin. Uzyskane wyniki, bez uwzględniania innych kryteriów uzależnienia od Internetu, muszą zastanawiać i niepokoić. Jeśli przyjmiemy jako punkt wyjścia 8 -godzinny dzień pracy ( 40 godzin w tygodniu), uzyskany wynik badania oznacza, że dla zdecydowanej większość ankietowanych praca wiąże się z Internetem. Ponadto, w przypadku $61 \%$ ankietowanych, Internet pochłania jeszcze od 10 do ponad 23 godzin, włączając $w$ to również soboty i niedziele. Rekordziści - $12 \%$ respondentów - spędzają w Internecie, bez względu na dzień tygodnia, minimum 9 godzin dziennie! Wywołuje to z pewnością wiele negatywnych skutków 
o charakterze psychofizycznym. Do najczęściej opisywanych należą ${ }^{51}$ : zaburzenia w sferze uczuć i emocji, zapominanie o posiłkach, utrwalanie postaw egocentrycznych, a nawet depresja. Terapeuci wskazuja także na liczne dolegliwości somatyczne, takie jak: pogorszenie wzroku, zaburzenia snu, tzw. padaczka ekranowa, a w skrajnych przypadkach inwalidyzujące zmiany fizyczne (np. zanik mięśni grzbietu) ${ }^{52}$.

Interpretując uzyskane wyniki w kontekście relacji międzyludzkich, zwłaszcza wymagań związanych z życiem małżeńskim i rodzinnym, stwierdzić należy $\mathrm{z}$ całą odpowiedzialnością, że w przypadku wskazanych $61 \%$ badanych, spędzających w Internecie ponad 50 godzin tygodniowo - o ile nie nastąpi jakaś radykalna zmiana $\mathrm{w}$ podejściu samych zainteresowanych do omawianego problemu - rozkład pożycia małżeńskiego i konsekwentnie rozwód wydają się kwestią czasu. Diagnozę taką potwierdzają także, równie niepokojące dane uzyskane od respondentów jako odpowiedź na kolejne pytanie: „Czy zdarza się Panu/Pani spędzić całą noc przed komputerem?”. Aż 89\% ankietowanych udzieliło odpowiedzi twierdzącej, w tym w przypadku $22 \%$ ankietowanych, zdarzyło się to kilka razy. Jeśli połączymy dane uzyskane z dwóch ostatnich pytań ankietowych, otrzymamy obraz osoby (w badanej próbie jest to większość 61\% ankietowanych), która spędza w Internecie średnio ponad 50 godzin tygodniowo, w tym zdarza się, że zajęciu temu poświęca całą noc. Nawet z punktu widzenia tzw. singli, są to przypadki, którymi powinien zainteresować się każdy terapeuta, a cóż dopiero, gdy opisana sytuacja dotyczy osób żyjących w rodzinach i mających na wychowaniu małoletnie dzieci. Klimat życia rodzinnego, jaki wyłania się z tych danych, jest więcej niż niepokojący. Pocieszający może być fakt, że respondenci wydają się zdawać sobie sprawę ze swego stanu. Na pytanie, ,czy uważa się Pan/i za oso-

51 Por. A. JAKUBIK, op. cit., s. 139 i n.

${ }^{52}$ Ibidem. O wpływie uzależnienia od Internetu na osobowość por. A. JAKUBIK, J. PopŁawska, Zespól uzależienia od Internetu (ZUI) a osobowość, «Studia Psychologica [UKSW]» 4 (2002), s. 123-131 (szczególnie, s. 128). 
bę uzależnioną od Internetu", 45\% badanych udzieliło odpowiedzi twierdzącej ${ }^{53}$.

Zarówno kryterium czasu „bycia w sieci”, jaki i liczby nocy spędzonych przed komputerem, chociaż samo w sobie jest zjawiskiem bardzo niepokojącym i rodzącym negatywne skutki w życiu osobistym i rodzinnym, nie jest jeszcze kryterium wystarczającym dla zweryfikowania faktu uzależnienia. Współczesne teorie w tym zakresie wymagają jak wcześniej wskazano, uwzględnienia innych jeszcze kryteriów. Zostały one wzięte pod uwagę w kolejnych pytaniach zawartych w omawianej ankiecie. Na podstawie uzyskanych wyników można wysnuć wniosek, że $10 \%$ respondentów spełnia kryteria uzależnienia. Kolejna grupa - $24 \%$ badanych - jest poważnie zagrożona uzależnieniem. Zdecydowana większość wśród nich stanowią osoby rozwiedzione ${ }^{54}$.

Część trzecia ankiety odnosiła się wyłącznie do osób rozwiedzionych. Uzyskane informacje w przedmiocie badania są o tyle cenne, że nie stanowią jedynie wiedzy teoretycznej respondentów, ale są wynikiem ich osobistego doświadczenia. Pierwsze z pytań dotyczyło przyczyn rozkładu pożycia (orzeczenia rozwodu). Respondenci wskazywali następujące przyczyny: niezgodność charakterów (41\%), zdrada (30\%), uzależnienie (17\%), kwestie finansowe $(7 \%)$, inne (5\%). Kolejne pytanie dotyczyło zdrady jako przyczyny rozwodu. Aż 78\% ankietowanych stwierdziło, że Internet ułatwił lub wprost spowodował

${ }^{53}$ Uzyskane $\mathrm{w}$ przedmiotowym badaniu wyniki odbiegają w pewnym stopniu od wyników innych badań dotyczących wykorzystania Internetu, publikowanych w literaturze. W wydanej ostatnio Diagnozie Internetu 2009, pod redakcją K. Kreutza, $95,7 \%$ respondentów przyznaje, że korzysta z Internetu codziennie, a $27,2 \%$ spędza w sieci więcej niż 5 godzin dziennie. Zastanawia przy tym, że duża liczba respondentów odmawia udzielenia dopowiedzi na temat stosowania określonej aplikacji internetowej. W przypadku gier internetowych jest to wielkość 16,5\% ogólnej liczby respondentów. Por. K. KReutz, Technologie cyfrowe i wykorzystanie Internetu, [w:] Diagnoza Internetu 2009, pod red. K. Kreutza, Warszawa 2009, s. 45.

${ }^{54}$ Uzyskane wyniki znajdują w pewnym stopniu potwierdzenie w innych badaniach. Z sondażu, jaki przeprowadzono wśród Europejczyków wynika, że ok. 10\% spośród nich przyznaje się do nałogowego używania Internetu. Por. P. Wallace, op. cit., s. 236-237. 
zdradę. Na kluczowe pytanie, „Czy uzależnienie od Internetu przyczyniło się do rozkładu Pana(i) małżeństwa?", aż 68\% badanych odpowiedziało twierdząco. Z kolei 53\% respondentów uznało uzależnienie od Internetu za jedyną przyczynę rozkładu pożycia w ich związku. Uzyskane wyniki powinny zastanawiać i niepokoić. Jednoznacznie potwierdzają one negatywny wpływ uzależnienia od Internetu na rozkład pożycia i rozwód. Szczególnie musi niepokoić skala zjawiska. Dla ponad połowy osób rozwiedzionych, które wzięły udział w badaniu, uzależnienie od Internetu było jedyną przyczyną rozpadu ich związku.

Przedstawione i skomentowane wyniki badań pozwalają na zweryfikowanie sformułowanych hipotez badawczych. W pełni potwierdziła się hipoteza pierwsza i zasadnicza - „Uzależnienie od Internetu może powodować rozkład pożycia małżeńskiego". Hipoteza ta znalazła potwierdzenie zarówno w poglądach respondentów na temat wpływu Internetu na wspólne pożycie, jak i w ich osobistych doświadczeniach - przeżyciu procesu rozkładu pożycia i rozwodu, spowodowanych uzależnieniem od Internetu. Prawie całkowicie potwierdziły się - niestety - również dwie inne hipotezy: hipoteza nr 3 - „Uzależnienie od Internetu wpływa negatywnie na więzi łączące małżonków" (72\%) oraz hipoteza $\mathrm{nr} 4$ - „Uzależnienie od Internetu ujemnie wpływa na zachowanie obowiązku wierności" (78\%). Nie potwierdziła się natomiast hipoteza nr 2 - „Zjawisko uzależnienia od komputera występuje głównie u osób, których praca wiąże się z Internetem".

\section{WNIOSKI}

Internet jako ciagle nowe jeszcze i nie w pełni poznane zjawisko jest przedmiotem licznych badań. Budzi on szczególne zainteresowanie zwłaszcza socjologów, z uwagi na fakt zmian jakie spowodował w globalnej strukturze społecznej i kulturze. Zmiany te wydają się na tyle głębokie i trwałe (zdaniem wielu nawet nieodwracalne), że kształtują nową globalną tożsamość społeczną. Jesteśmy określani co raz częściej jako „społeczeństwo sieci”"55.

55 Por. M. Castells, Społeczeństwo sieci, Warszawa 2008. 
Nie ulega wattpliwości, że powstanie Internetu i jego rozwój wyznacza zupełnie nowe tory rozwoju społecznego w każdej dziedzinie życia. W tym sensie jest on wartością pozytywną. Jak każde nowe zjawisko może jednak nieść z sobą również pewne niebezpieczeństwa. Ten wymiar Internetu staje się powoli i - jak się wydaje - co raz częściej również przedmiotem zainteresowania badaczy, zwłaszcza psychologów. Niniejszy artykuł wpisuje się w tę problematykę. Jego celem było zwrócenie uwagi na to, co w pierwszym spotkaniu z nowymi możliwościami postępu technologicznego zwykle umyka lub po prostu nie jest jeszcze dostatecznie rozpoznawane w zakresie wszystkich swych społecznych skutków, z braku koniecznego dystansu. Internet może stać się przedmiotem uzależnienia - to stwierdzenie nie budzi już dziś wątpliwości. Coraz głośniej mówią o tym terapeuci, rodzice, wychowawcy, a także najbardziej zainteresowani - osoby, które czują się i rzeczywiście są uzależnione. Społeczne skutki tego faktu są wielorakie i więcej niż niepokojące. Jednym z nich może być rozkład pożycia małżeńskiego i w konsekwencji rozwód.

Uzależnienie od Internetu jawi się jako jedna z możliwych przyczyn rozkładu pożycia małżeńskiego. Jej znaczenie jednak wydaje się wzrastać, tak w sensie ilościowym, jak i jakościowym. Po pierwsze dlatego, że ciaggle poszerza się zasięg oddziaływania Internetu. Jako społeczeństwo stanowimy ciągle jeszcze dla dostawców nowych usług tzw. rynek nienasycony, co oznacza, że liczba korzystających z Internetu będzie rosła z roku na rok, a wraz z nią prawdopodobieństwo nowych uzależnień. Po drugie uzależnienie od Internetu ma to do siebie, że może stać się i zazwyczaj staje się podłożem, na którym rozwijają się inne przyczyny rozkładu pożycia, jak np. niewierność. Zależność tę wyraźnie potwierdziły prezentowane w artykule wyniki badań nad wpływem uzależnienia od Internetu na pożycie małżeńskie. Badania te - chociaż nie spełniają kryteriów reprezentatywności i traktować je należy co najwyżej jako sondaż - są cennym źródłem informacji. Ich wyniki są na tyle niepokojące, że należy jak najszybciej przeprowadzić szerokie, reprezentacyjne ogólnopolskie badanie, celem poznania samego zjawiska i jego rzeczywistej skali. Konieczne wydaje się także wprowadzenie zmian w statystyce sądowej poprzez wprowadzenie nowej 
odrębnej przyczyny rozwodu - uzależnienia od Internetu. Pozwoliłoby to śledzić w praktyce orzeczniczej kształtowanie się analizowanego zjawiska i poznać w pełni społeczne skutki jego oddziaływania.

Prezentowane tu wyniki badań skłaniają do jeszcze jednego wniosku. Grupą najbardziej narażoną na negatywny wpływ nowego środka przekazu informacji są dzieci i młodzież. Konieczne i pilne wydaję się opracowanie programu, którego celem byłoby upowszechnienie wiedzy na temat negatywnych skutków nadużywania komputera i uczenie właściwego zeń korzystania. Pomoc taka jest potrzebna zwłaszcza rodzicom, którzy, jak pokazują badania ${ }^{56}$, są bezradni wobec wpływu Internetu na ich dzieci. Potrzebna jest tu szeroka współpraca wszystkich instytucji i grup społecznych, bo tylko wtedy możliwy jest pozytywny skutek podjętych działań.

\section{Addiction to Internet as a Possible Reason of Divorce}

\section{Summary}

The article deals with problem of the addiction to the Internet as one of possible reasons of divorce. In the first part - theoretical - the Author tries to describe the phenomenon of addiction, its phases and consequences. In the second part there have been presented a results of the researches of the influence of addictions to the Internet on the quality of the relationship between spouses. The conclusion is that the Internet can be the cause of addiction. Its influence on relationship between the spouses can be destructive, it can lead to conflicts and finally to divorce. The Author postulates of all-Polish researches on the scale of this phenomenon and its negative social effects.

56 Por. S. OlczaK, Aspekty psychoterapii osób uzależnionych od komputera i Internetu, «Terapia Uzależnienia i Współuzależnienia» $2007 \mathrm{nr}$ 6, s. 31 i n. 